\title{
NOTE ON CONTRIBUTORS
}

Torsten Andreasen is a postdoc in the research project "Finance Fiction-Financialization and Culture in the Early 21st Century" at the Department of Arts and Cultural Studies, University of Copenhagen. Recent publications include "Finance Fiction" in The Routledge Companion to Critical Finance Studies (along with Mikkel Krause Frantzen and Frederik Tygstrup), "Subjektivitet" in Lund \& Schmidt (eds.): Medieastetik: En introduktion, and "Destituting the Interface: Beyond Affordance and Determination" in Media Theory.

Solveig Daugaard's research field is modernist and contemporary American poetry and contemporary Scandinavian literature and media theory. Her criticism has appeared in Jacket 2 and in a number of journals and papers in Denmark, Sweden and abroad, and her dissertation Collaborating with Gertrude Stein is under revision and forthcoming from the University of Alabama Press (2021). She is currently a teacher and a postdoctoral researcher affiliated with the School of Arts and Communications, Malmö University, and the Department of Arts and Cultural Studies, University of Copenhagen. Her PhD in Literature, Media History and Information Cultures is from Linköping University.

Mikkel Krause Frantzen is a postdoc at the Department of Arts and Cultural Studies, University of Copenhagen, where he is part of the research project "Finance Fiction-Financialization and Culture in the Early 21st Century.” The author of Going Nowhere, Slow (Zero Books, 2019), his work has appeared in Critique: Studies in Contemporary Fiction, Journal of Austrian Studies, Studies in American Fiction, boundary2, SubStance, Third Text, Theory, Culture, and Society, and Los Angeles Review of Books.

Kristina Hermansson is senior lecturer in comparative literature at the University of Gothenburg, specializing in children's and youth fiction. Hermansson's research interests are in the area of critical theory, including ideology, class, gender, and spatiality. She has published studies of novels, mum lit, and numerous articles on picture books, with a strong emphasis on Nordic literature. 
Nicholas Huber is a postdoc in the Department of Arts and Cultural Studies at the University of Copenhagen. His writing on money, work, class, and contemporary fiction can be found at Theory \& Event, NOVEL: A Forum on Fiction, and Open Library of the Humanities.

Emma Sofie Brogaard Jespersen is an MA student in Comparative Literature at the Department of Arts and Cultural Studies at University of Copenhagen. She is a student assistant at the research projects "Finance Fiction-Financialization and Culture in the Early 21st Century" and "Art as Forum” at UCPH. She works, moreover, as an editorial assistant at the Danish publishing house Informations Forlag.

Vera Knútsdóttir is a $\mathrm{PhD}$ student in the department of Comparative Literature at the University of Iceland. She is working on the final touches of her doctoral thesis, written under the supervision of prof. Gunnthórunn Gudmundsdóttir, and titled Spectral Memories of Icelandic Culture: Memory, Identity and the Haunted Imagination in Contemporary Literature and Art. Vera is currently based in Copenhagen.

Kristina Malmio, PhD, Docent and University Lecturer in Nordic literature at the University of Helsinki, has written extensively on Swedish literature in Finland in the twentieth and early twentyfirst century. Her research areas include literary spatiality, theories on postmodernism and beyond, and the relation between literature and society. Among her recent publications are the co-edited Contemporary Nordic Literature and Spatiality (2019) and the article “'Welche Sprachen sprechen Cyborgs?' Mehrsprachigkeit und Technologie in der skandinavischen Gegenwartsliteratur,” written together with Sophie Wennerscheid and published in Multilingualität und Mehr-Sprachligkeit in der Gegenwartsliteratur.

Mary Poovey is professor emerita at New York University. She is a scholar of nineteenth century British literature and culture, feminist theory, and economic history. Her latest books are The Financial System in Nineteenth-Century Britain (2003), Genres of the Credit Economy: Mediating Value in Eighteenth and NineteenthCentury Britain (2008), and along with Kevin R. Brine: Finance in America: An Unfinished Story (2017). 
Dominique Routhier is a Post-Doctoral Researcher at the Department for the Study of Culture, University of Southern Denmark. PhD (2020) with a dissertation entitled The Work of Art in the Age of Automation: The Situationist Movement, 19561968, now being reworked into a book. Publications in various Scandinavian and international journals such as Monsieur Antipyrine, Agora, $K \& K$ and Rethinking Marxism. Currently affiliated with the research project "Drone Imaginaries and Communities” (Independent Research Fund Denmark, 20202024).

Frederik Tygstrup is Academic Director of Copenhagen Doctoral School in Cultural Studies and professor of comparative literature, University of Copenhagen. Presently, heisthe principalinvestigator of two research projects: "Finance Fiction-Financialization and Culture in the Early 21st Century” (Danish Research Council 20182021) and "Art as Forum. The New Carlsberg Research Center" at the University of Copenhagen (2020-2024). His latest publications include "Topologies of Debt" in Differences Vol. 3(Duke University Press, 2020), "De te fabula narratur!" in Charles Armstrong et al. (eds.): Terrorizing Images in the Literature of Trauma (Brill, 2020), and "Figura" in Kristin Veel et al. (eds.): Uncertain Archives. Critical Terms for Big Data (MIT Press, 2021).

Joseph Vogl is Professor for Literature and Cultural Theory (Kulturwissenschaft) at the Humboldt-Universität Berlin and permanent Visiting Professor at the Department of German at Princeton University. His latest books are Das Gespenst des Kapitals (2010) and Der Souveränitätseffekt (2015). 